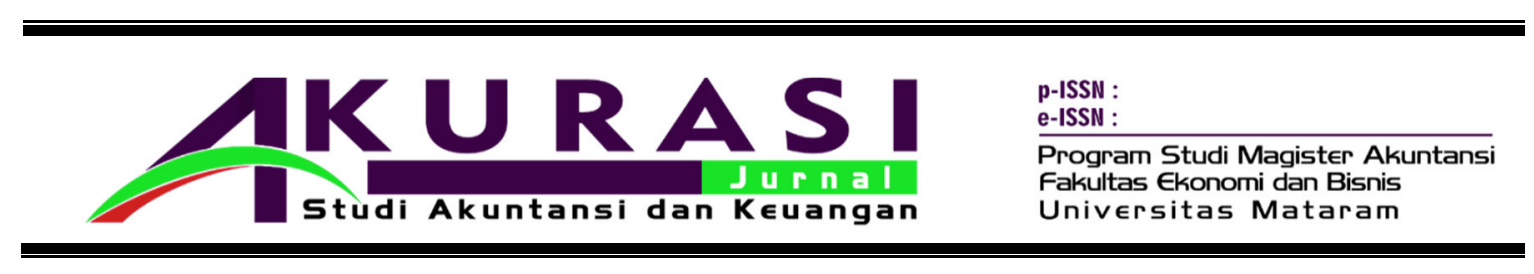

\title{
ANALISIS PERMASALAHAN PENGELOLAAN DANA ALOKASI UMUM DAN DANA ALOKASI KHUSUS PADA PEMERINTAH DAERAH
}

\author{
Uun Ainul Yaqin ${ }^{1}$, Titiek Herwanti ${ }^{2}$ \\ ${ }^{I}$ Magister Akuntansi Universitas Mataram, uunainulyaqin2508@gmail.com \\ ${ }^{2}$ Universitas Mataram, titikherwanti@unram.ac.id
}

INFORMASI ARTIKEL

Article history:

Dikirim tanggal: date

Revisi pertama tanggal: date

Diterima tanggal: date

Tersedia online tanggal dd/mm/yyyy

\section{A BSTRAK}

Tujuan penelitian ini adalah untuk menganalisis permasalahan pada pengelolaan Dana Perimbangan baik pada DAU dan DAK dengan menggunakan pendekatan kualitatif. Pengumpulan data menggunakan metode wawancara, dokumentasi dan observasi lapangan. Hasil penelitian menunjukkan bahwa pengelolaan dana perimbangan baik DAU maupun DAK di daerah belum optimal. Besarnya anggaran dana transfer dari pusat berupa DAU tidak di ikuti dengan besarnya pengeluaran dalam bentuk belanja modal, karena DAU lebih didominasi oleh belanja pegawai yang berarti bahwa pada umumnya pemerintah daerah masih berkonsentrasi kepada masalah administrasi, sehingga belum efektif dalam meningkatkan pelayanan publik. Demikian juga dengan pengalokasian DAK yang belum efektif dan belum berorientasi pada anggaran berbasis kinerja. Hal ini karena arah penggunaan DAK lebih cenderung berfokus pada input bukan pada outcome yang dapat meningkatkan pelayanan publik, kesejahteraan masyarakat dan memajukan perekonomian daerah.

Kata Kunci: Dana Perimbangan, Dana Alokasi Umum (DAU), Dana Alokasi Khusus (DAK),

\section{ABSTRACT}

The purpose of this study was to analyze problems in the management of the Balance Fund both in the management of General Allocation Fund and Special Allocation Fund using a qualitative approach. Data collection uses interview, documentation and field observation methods. The results showed that the management of balancing funds in both the General Allocation Fund and Special Allocation Fund in the regions was not optimal. The amount of the transfer fund from the center in the form of General Allocation Fund is not followed by the amount of expenditure in the form of capital expenditure, because General Allocation Fund is dominated by personnel expenditure which means that in general the regional government is still concentrating on administrative issues, so it has not been effective in improving public services. Likewise, the allocation of Special Allocation Fund has not been effective and has not been oriented to performance-based budgets. This is because the direction of the use of Special Allocation Fund is more likely to focus on inputs rather than on outcomes that can improve public services, improve people's welfare and advance the regional economy.

Keywords: Balance Fund, General Allocation Fund, Special Allocation Fund

(C)2018 FEB UNRAM. All rights reserved 


\section{Pendahuluan}

Otonomi daerah dapat di artikan sebagai penyerahan sejumlah wewenang dari pemerintah pusat ke pemerintah daerah, salah satu faktor yang menentukan keberhasilan pelaksanaan otonomi daerah adalah kemampuan daerah untuk membiayai pelaksanaan kekuasaan dan wewenang yang dimilikinya. Dalam era otonomi daerah tidak lagi sekedar menjalankan instruksi dari pusat, tetapi benar-benar mempunyai keleluasaan untuk meningkatkan kreativitas dalam mengembangkan potensi (Mardiasmo, 2002). Pemerintah daerah diharapkan semakin mandiri, mengurangi ketergantungan terhadap pemerintah pusat, bukan hanya terkait dengan pembiayaan, tetapi juga terkait dengan kemampuan pengelolaan daerah yang diharapkan semakin meningkatkan pelayanan publik.

Otonomi daerah di satu sisi memberikan kewenangan yang lebih besar dalam hal pengelolaan daerah secara mandiri akan tetapi disisi lain memunculkan persoalan baru di karenakan tingkat kesiapan fiskal setiap daerah yang berbeda beda. Oleh karena itu Pemerintah Pusat mengeluarkan UU No. 33 Tahun 2004 tentang dana Perimbangan yang terdiri dari Dana Alokasi Umum (DAU), Dana Alokasi Khusus (DAK), dan Dana Bagi Hasil (DBH). Tujuannya adalah untuk mengurangi ketimpangan daerah sebagai akibat dari perbedaan kondisi dan potensi yang tidak sama antar daerah, pemberian dana perimbangan ini ditujukan untuk mengurangi adanya disparitas fiskal vertikal (antara pemerintah pusat dengan pemerintah daerah) dan horizontal (antar pemerintah daerah), sekaligus untuk membantu daerah dalam membiayai pengeluaran pembangunannya. Namun demikian pengelolaan dana perimbangan belum sepenuhnya mampu menciptakan pemerataan kemampuan keuangan daerah secara optimal, terutama bagi wilayah kabupaten dan kota. Kondisi ini di sebabkan formula perhitungan dana perimbangan yang perlu penyempurnaan (Nurkhayat et al., 2018)

Permasalahan terkait dengan pelaksanaan otonomi daerah yaitu kemampuan mengelola keuangan pemerintah daerah. Pengelolaan keuangan daerah didefinisikan sebagai keseluruhan kegiatan yang meliputi perencanaan, pelaksanaan, penatausahaan, pelaporan, pertanggungjawaban, dan pengawasan keuangan daerah. Keberhasilan dari suatu pembangunan di daerah tidak terlepas dari aspek pengelolaan keuangan daerah yang harus dikelola dengan manajemen yang baik pula. Pengelolaan keuangan daerah harus dikelola secara tertib, taat pada peraturan perundang-undangan, efektif, efisien, ekonomis, transparan, dan bertanggung jawab dengan memperhatikan azas keadilan, kepatutan, dan manfaat untuk masyarakat. Pada kenyataannya pengelolaan keuangan masih menjadi masalah di daerah. Kementerian Keuangan (Kemenkeu) menyatakan terdapat beberapa indikator yang menunjukkan pengelolaan anggaran di daerah tidak efisien. Salah satu nya terkait dengan jumlah belanja pegawai yang jauh lebih besar dibanding belanja modal dimana Alokasi DAU banyak tersedot untuk belanja pegawai. Menteri Keuangan Sri Mulyani menyampaikan dalam sosialisasi transfer ke daerah pada anggaran 2019 di Kemenkeu pada senin (10/12/2018) menyatakan bahwa DAU yang seharusnya di gunakan untuk peningkatan penyediaan layanan masyarakat justru digunakan untuk membiayai belanja rutin. Lebih lanjut Menteri Keuangan Sri Mulyani menegaskan bahwa dana transfer daerah yang selama ini dialokasikan melalui APBN tak banyak membantu dalam percepatan pembangunan. Hal ini karena sebagian besar dana itu habis untuk belanja pegawai ketimbang belanja modal. Lebih lanjut ekonom dan peneliti dari Indef, Enny Sri Hartati menyampaikan penyebab utama permasalahan pada dana transfer adalah penggunaan dana yang tidak sesuai karena selama ini dana transfer berupa Dana Alokasi Umum memang tidak efektif untuk menggenjot pembangunan di daerah.

DAU atau general purpose grant atau block grants yaitu dana yang bersumber dari pendapatan APBN yang dialokasikan dengan tujuan pemerataan kemampuan 
keuangan antardaerah untuk mendanai kebutuhan daerah dalam rangka pelaksanaan desentralisasi. Oleh karena DAU bersifat Block Grants sehingga daerah dapat dengan leluasa memanfaatkan dana tersebut untuk kebutuhan yang diinginkan. Namun, masalah yang muncul adalah kemampuan daerah dalam mengelola DAU. Apabila daerah kurang mampu mengelola dana tersebut, maka tidak menutup kemungkinan yang terjadi adalah semakin meningkatnya ketergantungan daerah pada dana perimbangan. Berikut di sajikan data Penerimaan Pendapatan Daerah terdiri dari PAD, Dana Perimbangan Kota Bima Tahun 2012-2016.

Tabel 1. Penerimaan Pendapatan Daerah PAD, Dana Perimbangan Kota Bima Tahun 2012-2016

\begin{tabular}{cccccc}
\hline \multirow{2}{*}{ TAHUN } & \multirow{2}{*}{ PAD } & \multicolumn{4}{c}{ Dana Perimbangan (dalam ribuan rupiah) } \\
\cline { 3 - 6 } & & DAU & DAK & DBH & TOTAL \\
\hline 2012 & 10.737 .705 & 314.481 .500 & 30.659 .595 & 26.758 .175 & 362.782 .788 \\
& & & & & \\
2013 & 15.691 .113 & 377.377 .812 & 40.879 .460 & 25.832 .470 & 444.089 .742 \\
2014 & 23.665 .603 & 410.483 .310 & 33.992 .090 & 23.247 .904 & 467.723 .304 \\
2015 & 30.266 .723 & 435.279 .239 & 98.875 .020 & 18.252 .679 & 552.406 .938 \\
2016 & 30.524 .800 & 464.125 .442 & 172.662 .913 & 62.125 .501 & 698.913 .856
\end{tabular}

Sumber Data: Realisasi APBD Kota Bima

Berdasarkan data dari BPKAD Kota Bima terkait dengan realisasi penerimaan dana perimbangan Kota Bima Tahun 2012-2016 menunjukan bahwa pemerintah Kota Bima selama kurun waktu 5 (lima) tahun mengandalkan DAU sebagai penyumbang pendapatan daerah terbesar dengan presentasi mencapai 72\%, DAK sebesar 14\%, DBH sebesar $6 \%$, PAD sebesar 4\% dan lain-lain pendapatan daerah yang sah sebesar 5\%.Terlihat bahwa DAU sangat mendominasi penerimaan daerah, akan tetapi formula alokasi DAU saat ini masih banyak terdistorsi, sehingga perannya sebagai equalization grant tidak optimal. Selain itu dalam alokasi belanjanya, fakta menunjukkan bahwa porsi belanja pegawai negeri sipil daerah dalam APBD relatif cukup besar, dimana Pengalokasian DAU ini di peruntukkan untuk Belanja Pegawai dimana dalam kurun waktu 2012-2016 mencapai 58\% dari total belanja daerah. Fakta ini menunjukkan bahwa pada umumnya pemerintah daerah masih berkonsentrasi kepada masalah administrasi, sehingga belum maksimal untuk meningkatkan pelayanan publik.

Instrumen kebijakan desentralisasi fiskal yang secara langsung dapat memengaruhi kualitas belanja pemerintah daerah adalah dana alokasi khusus (DAK). Dana alokasi khusus adalah dana yang bersumber dari pendapatan APBN yang dialokasikan kepada daerah tertentu dengan tujuan untuk membantu mendanai kegiatan khusus yang merupakan urusan daerah dan sesuai dengan prioritas nasional. Kegiatan khusus dalam Undang-Undang tersebut berupa difokuskan pengadaan atau perbaikan infrastruktur fisik guna pelayanan publik dan penyediaan infrastruktur.

Berdasarkan data di atas menunjukan bahwa DAK sesungguhnya bukanlah dana yang besar dalam keseluruhan Dana Perimbangan. Walaupun kontribusi DAK kecil hanya sekitar $14 \%$ dari total dana perimbangan Pemerintah Kota Bima, DAK memainkan peran strategis dalam dinamika pembangunan sarana dan prasarana pelayanan dasar di daerah, karena sesuai dengan prinsip desentralisasi dan akuntabilitas bagi penyediaan pelayanan dasar masyarakat. Mengingat strategisnya peran DAK tersebut maka di dalam pengelolaannya harus dilakukan secara efektif, efisien dan mencerminkan suatu semangat tata pemerintahan yang baik (good government 
governance) mulai dari aspek kebijakan, perencanaan, alokasi, pelaksanaan, pemantauan dan evaluasinya.

Fakta yang terjadi bahwa pengalokasian DAK di banyak daerah masih belum efektif pelaksanaannya, sehingga DAK yang di lontarkan belum mampu untuk memberikan peningkatan pelayanan pada masyarakat. Hasil kajian ADB (2011) mengenai analisis permasalahan dan dampak dana alokasi khusus selama ini belum memberikan kontribusi signifikan terhadap tujuan (outcomes dan impact) pembangunan di daerah. Lebih lanjut dalam kajian tersebut dipaparkan bahwa permasalahan utama kurang tercapainya dampak DAK bukan terletak pada kecilnya jumlah DAK, tetapi lebih pada kurang efisiennya pengalokasian DAK serta kurang efektifnya tata kelola implementasi DAK. Hal ini terjadi karena pendekatan pencapaian yang berlaku di Indonesia adalah pendekatan berbasis input, dimana DAK hanya dapat dibelanjakan untuk jenis input tertentu tidak berdasarkan dari output maupun outcome sehingga sasaran DAK ini belum dapat di ukur pencapaiannya.

Studi yang dilakukan oleh Nuryadin dan Sri (2017) meneliti tentang analisis dan evaluasi dampak dana alokasi khusus terhadap indikator kinerja pembangunan di daerah secara tidak langsung menunjukkan juga bahwa alokasi DAK (secara total) tidak signifikan berpengaruh terhadap PDRB per kapita Kabupaten/Kota. Temuan studi tersebut mengindikasikan bahwa DAK, baik menurut alokasi bidang maupun secara total, belum memberikan dampak yang signifikan terhadap pelayanan publik dan kesejahteraan masyarakat. Hal ini dikarenakan memang arah penggunaan DAK yang memang tidak atau belum secara langsung digunakan untuk membangun, namun hanya untuk memelihara. Oleh karena itu, DAK dirasa belum cukup efektif dalam upaya mencapai sasaran prioritas nasional yang menjadi bagian dari urusan daerah. Demikian halnya pada Pemerintahan Kota Bima Berdasarkan penelitian yang dilakukan oleh Yaqin et.al (2018) menunjukan bahwa pengalokasian belanja daerah untuk DAK belum efektif, pengalokasian DAK tidak berhasil guna, sehingga tidak memberikan dampak pada peningkatan kesehateraan masyarakat karena outcome belum bisa diukur yaitu dampak dari penyelenggaraan kegiatan pemerintah tersebut pada peningkatan kesejahteraan masyarakat.

Dari beberapa permasalahan mengenai Dana Alokasi Khusus (DAK) yang sudah di paparkan di atas sudah seharusnya pengalokasian DAK perlu di tingkatkan pelaksanaan kegiatan nya sehingga pengalokasian dapat dilaksanakan secara efektif dan tepat sasaran sehingga dapat berdampak pada peningkatan pelayanan kepada masyarakat. Begitu hal nya dengan DAU diperlukan penyempurnaan formula DAU agar benar-benar harus diprioritaskan mengingat DAU merupakan komponen pembiayaan terbesar dari Dana Perimbangan sekaligus sumber penerimaan terbesar bagi sebagian besar daerah termasuk Pemerintah Kota Bima sehingga diharapkan dana yang besar ini pengalokasiannya tidak hanya untuk gaji pegawai. Dengan demikian pengalokasiam Dana Perimbangan baik DAK maupun DAU diharapkan mampu meningkatan pelayanan publik dan pertumbuhan ekonomi di daerah. Hasil penelitian ini memberikan kontribusi bagi pemerintah pusat serta pemerintah daerah, untuk mengoptimalkan pelaksanaan kebijakan yang ada di daerah, seperti PP RI No. 12 Tahun 2017 tentang pembinaan dan pengawasan pada pemerintah daerah agar anggaran yang di alokasikan daerah dalam bentuk dana perimbangan baik DAU maupun DAK tepat sasaran dan dapat meningkatkan Pembangunan daerah.

\section{Kerangka Teoretis dan Kerangka Pikir Penelitian}

Implementasi kebijakan adalah tindakan yang dilakukan baik oleh individu, pejabat atau kelompok pemerintah atau swasta yang diarahkan pada terciptanya tujuan yang telah digariskan dalam keputusan kebijaksanaan (Agustino, 2016). Implementasi 
kebijakan merupakan suatu proses yang dinamis sehingga keberhasilan implementasi kebijakan dapat diukur dari proses yaitu apakah pelaksanaan program telah sesuai dengan yang ditentukan dan apakah tujuan dan hasil akhir telah tercapai. Teori Implementasi Kebijakan digunakan dalam penelitian ini untuk menjustifikasi tindakan pemerintah daerah dalam pengalokasian dana perimbangan DAU dan DAK dalam memberikan pelayanan kepada publik untuk meningkatkan kesejahteraan masyarakat.

Menurut UU Nomor 32 Tahun 2004 tentang Pemerintahan Daerah Pasal 1 ayat 5 menyatakan bahwa "Otonomi daerah adalah hak, wewenang, dan kewajiban daerah otonom untuk mengatur dan mengurus sendiri urusan pemerintahan dan kepentingan masyarakat setempat sesuai dengan peraturan perundang-undangan", dari pengertian tersebut diartikan bahwa otonomi daerah merupakan kemerdekaan atau kebebasan menentukan aturan sendiri berdasarkan perundang-undangan, dalam memenuhi kebutuhan daerah sesuai dengan potensi dan kemampuan yang dimiliki oleh daerah (Halim, 2007). Tujuan pemberian otonomi daerah adalah untuk memungkinkan daerah yang bersangkutan mengatur dan mengurus rumah tangga sendiri dalam rangka meningkatkan daya guna dan hasil guna penyelenggaraan pemerintahan bagi pelayanan masyarakat dan pelaksanaan pembangunan (Handayani, 2009). Sebagai upaya untuk mencapai tujuan itu, maka kepada daerah diberikan wewenang untuk melaksanakan urusan pemerintahan. Otonomi daerah membawa dua implikasi khusus bagi pemerintah daerah yaitu pertama adalah semakin meningkatnya biaya ekonomi (high cost economy) dan yang kedua adalah efisiensi dan efektifitas. Oleh karena itu desentralisasi membutuhkan dana yang memadai bagi pelaksanaan pembangunan di daerah. Apabila suatu daerah tidak memiliki sumber-sumber pembiayaan yang memadai maka dari hal ini akan mengakibatkan daerah bergantung terus terhadap pembiayaan pemerintah pusat. Ketergantungan terhadap pembiayaan pemerintah pusat merupakan kondisi yang tidak sesuai dengan asas otonomi daerah. Oleh karena itu perlu suatu upaya oleh pemerintah daerah dalam memutus ketergantungan tersebut dalam rangka meningkatkan kemampuan daerah.

Salah satu bentuk dari pemberian otonomi dari pemerintah pusat ke pemerintah daerah adalah desentralisasi fiskal di bidang keuangan kepada daerah-daerah yang merupakan suatu proses pengintensifikasian peranan dan sekaligus pemberdayaan daerah dalam pembangunan. Desentralisasi fiskal memerlukan pergeseran beberapa tanggung jawab terhadap pendapatan (revenue) dan/atau pembelanjaan (expenditure) ke tingkat pemerintahan yang lebih rendah. Melalui desentralisasi fiskal akan terjadi pelimpahan wewenang dibidang penerimaan anggaran atau keuangan yang sebelumnya tersentralisasi, baik secara administrasi maupun pemanfaatannya diatur atau dilakukan oleh pemerintah pusat, dengan terjadinya pelimpahan sebagian wewenang terhadap sumber-sumber penerimaan di daerah, diharapkan daerah-daerah dapat melaksanakan tugas-tugas rutin, pelayanan publik dan meningkatkan investasi yang produktif (capital investment) di daerahnya.

Kerangka pikir penelitian ini mengargumentasikan bahwa sebagai konsekuensi dari otonomi daerah maka transfer dana perimbangan dari pemerintah pusat kepada pemerintah daerah perlu dikelola dengan optimal untuk tujuan memberikan pelayanan publik dan kesejahteraan masyarakat. Namun demikian faktanya pengalokasian DAU dan DAK tidak sesuai dan lebih banyak digunakan untuk pengeluaran operasional yang sifatnya rutin daripada untuk peningkatan sarana pelayanan publik dan programprogram untuk meningkatkan kesejahteraan kepada masyarakat. Berdasarkan kesenjangan dalam fenomena tersebut maka efektivitas penggunaan dana perimbangan baik DAU maupun DAK perlu ditingkatkan untuk dialokasikan ke belanja yang mendukung peningkatan pelayanan publik dan pertumbuhan ekonomi di daerah. Hal ini karena pengalokasian DAU harus diprioritaskan mengingat DAU merupakan komponen 
pembiayaan terbesar dari Dana Perimbangan sekaligus sumber penerimaan terbesar bagi Pemerintah daerah sehingga mampu meningkatan pelayanan publik dan pertumbuhan ekonomi di daerah. Di sisi lain pengalokasian DAK berperan strategis dalam pembangunan sarana dan prasarana pelayanan dasar di daerah, sudah seharusnya pengalokasian DAK ini sendiri dilakukan secara efektif guna mendorong pencapaian pelayanan dasar di daerah. Dengan demikian alokasi dana perimbangan, baik DAU maupun DAK, perlu ditingkatkan efektivitasnya melalui pelaksanaan monitoring dan evaluasi sehingga dapat meningkatkan kinerja pemerintah daerah, terutama berkaitan dengan kinerja dan capaian program yang sudah dilaksanakan oleh pemerintah daerah.

\section{Metode Penelitian}

Penelitian ini menggunakan pendekatan kualitatif untuk memahami, mengamati dan melakukan eksplorasi yang lebih dalam dan pengungkapan secara detail dalam memahami permasalahan terkait Pengelolaan Dana Perimbangan Kota Bima berupa DAU dan DAK. Dalam penelitian ini pendekatan yang dilakukan adalah melalui pendekatan kualitatif dengan studi kasus (case study). Penelitian studi kasus memusatkan diri secara intensif pada suatu objek tertentu yang mempelajarinya sebagai suatu kasus. Penelitian studi kasus dimaksudkan untuk mempelajari secara intensif tentang latar belakang masalah, keadaan dan posisi suatu peristiwa yang sedang berlangsung saat ini, serta interaksi unit sosial tertentu yang bersifat apa adanya (given).

Untuk memperoleh data dan informasi yang dibutuhkan dalam penelitian, dilakukan dengan wawancara secara mendalam terhadap informan yang dijadikan sebagai narasumber informasi. Penentuan informan dilakukan dengan menggunakan teknik purposive sampling. Informan yang di pilih adalah informan yang terlibat langsung serta memahami dan dapat memberikan informasi tentang topik penelitian. Adapun Informan ini terdiri dari TAPD Kota Bima, selain itu informan dalam penelitian ini juga melibatkan Kabid Perencanaan Ekonomi di Bappeda Kota Bima. Penentuan infoman yang didapatkan dalam penelitian ini dianggap mampu memahami dan untuk memberikan informasi secara mendalam terkait masalah yang diteliti.

Dalam Penelitian ini, teknik pengumpulan data yang digunakan dalam penelitian adalah wawancara, dokumentasi dan observasi. Salah satu sumber informasi studi kasus yang sangat penting adalah wawancara karena dengan melakukan wawancara akan dapat memperoleh kedalaman dan rincian informasi yang dibutuhkan. Pedoman dalam wawancara yang digunakan dalam penelitian ini adalah wawancara tidak terstruktur (unstructured interview), yaitu peneliti tidak menggunakan pedoman yang telah tersusun secara sistematis dan lengkap untuk pengumpulan datanya. Pertanyaan disesuaikan dengan keadaan dari informan pelaksana dan pertanyaan dikembangkan pada saat wawancara berlangsung sehingga wawancara mengalir seperti percakapan sehari-hari. Hal ini dimaksudkan agar proses wawancara terjadi dengan alami dan mendalam seperti yang diharapkan dalam penelitian kualitatif. Dokumentasi adalah metode yang digunakan untuk menelusuri data historis yang berupa catatan dan sumbersumber dokumen lainnya yang dapat dimanfaatkan sebagai bukti dari kejadian tertentu atau sebagai bentuk pertanggungjawaban untuk keperluan penelitian. Observasi partisipatif studi lapangan untuk menghimpun data penelitian melalui observasi khusus dimana peneliti tidak hanya menjadi pengamat pasif, tetapi juga mengambil peran dalam situasi dan berpartisipasi dalam peristiwa yang akan di teliti.

Analisis data dalam penelitian ini mengacu pada teknik data kualitatif oleh Miles dan Huberman sebagimana dikutip dalam (Sugiyono,2014) yang menjelaskan bahwa aktivitas analisis data kualitatif di lakukan secara terus-menerus pada setiap tahapan penelitian, sehingga data yang diperoleh sampai tuntas dan sampai jenuh. Adapun analisis data dalam penelitian ini menggabungkan prosedur analisis data model 
Miles dan Huberman (1992) dalam tiga tahapan yang harus dikerjakan dalam menganalisis data penelitian kualitatif yaitu reduksi data (data reduction), Paparan data (data display), penarikan kesimpulan dan verifikasi (conclusion drawing/verifying).

\section{Hasil dan Pembahasan}

Dampak berlakunya otonomi dan desentralisasi terhadap pengelolaan keuangan daerah adalah semakin luasnya kewenangan pemerintah daerah mengelola dana masyarakat berupa APBD, untuk meningkatkan pelayanan publik, kesejahteran masyarakat dan memajukan perekonomian daerah. Pemerintah daerah dituntut untuk mengelola dana tersebut secara lebih transparan, ekonomis, efisien, efektif dan akuntabel, sehingga dapat memberikan manfaat berupa efektivitas pelayanan kepada masyarakat, meningkatkan mutu pelayanan kepada masyarakat, alokasi belanja yang lebih berorientasi pada kepentingan publik, menghilangkan setiap inefiensi dalam seluruh tindakan pemerintah dan melakukan penghematan dalam pemakaian sumber daya, serta mewujudkan pemerintah yang baik dan terbuka terhadap kepentingan masyarakat (LAKIP Kota Bima, 2016). Untuk dapat menciptakan efisiensi, efektivitas dan akuntabel pengelolaan sumber daya daerah tersebut, maka anggaran daerah sebagai salah satu alat kebijakan pemerintah daerah dalam upaya pencapaian visi dan misi pembangunan sudah selayaknya diarahkan seoptimal mungkin.

Pada kenyataannya pengelolaan keuangan di daerah belum dilaksanakan secara optimal dalam menunjang peningkatan pembangunan di daerah. Kementerian Keuangan (Kemenkeu) secara eksplisit menyatakan bahwa terdapat beberapa indikator yang menunjukkan pengelolaan anggaran di daerah tidak efisien. Salah satu nya terkait dengan jumlah belanja pegawai yang jauh lebih besar dibanding belanja modal dimana Alokasi DAU banyak tersedot untuk belanja pegawai.

Berdasarkan data dari Badan Pengelolaan Keuangan dan Aset Daerah (BPKAD) Kota Bima tahun 2017, belanja modal pemerintah Kota Bima dalam kurun waktu 2012-2016 hanya mencapai rata-rata 21\% dari total belanja daerah, sedangkan belanja operasi mencapai angka rata-rata $77 \%$ dari belanja daerah. Hal ini menyebabkan keterbatasan program dan kegiatan daerah yang bisa didanai khususnya dalam mendukung pemenuhan layanan publik karena belanja digunakan untuk belanja rutin yang kurang produktif. Adapun perbandingan realisasi belanja modal dan belanja operasi Kota Bima tahun 2012-2016 disajikan pada tabel 2 berikut ini :

Tabel 2. Realisasi Belanja Modal dan Belanja Operasi terhadap total Belanja Daerah Kota Bima Tahun Anggaran 2012-2016

\begin{tabular}{lccccc}
\hline Tahun & $\begin{array}{c}\text { Belanja Modal } \\
\text { (BM) }\end{array}$ & $\begin{array}{c}\text { Belanja } \\
\text { Operasi }\end{array}$ & $\begin{array}{c}\text { Belanja Daerah } \\
\text { (BD) }\end{array}$ & \multicolumn{2}{c}{ Persentase (\%) } \\
BM/BD & BO/BD \\
\hline 2012 & 73.078 .783 .471 & 298.548 .799 .816 & 372.959 .295 .477 & 19 & 80 \\
2013 & 103.388 .469 .782 & 428.536 .141 .949 & 533.340 .838 .221 & 19 & 80 \\
2014 & 119.525 .159 .428 & 480.416 .764 .067 & 600.919 .276 .495 & 19 & 79 \\
2015 & 175.011 .396 .228 & 568.886 .986 .573 & 704.320 .191 .402 & 24 & 74 \\
2016 & 217.145 .998 .258 & 568.886 .986 .573 & 788.330 .723 .322 & 27 & 72 \\
\hline
\end{tabular}

Sumber Data: BPKAD Kota Bima (2016, diolah)

Tabel 2 menunjukan perkembangan belanja modal daerah Kota Bima dari tahun ke tahun mengalami perkembangan secara nominal, dimana pada tahun 2012 belanja modal sebesar Rp. 73.078 milyar, tahun 2013 meningkat sebesar Rp. 103.388 milyar. Pada tahun 2014 meningkat sebesar Rp. 119.522 Milyar hingga pada tahun 2015 
meningkat sebesar Rp. 175.011 milyar sampai pada tahun 2016 terus mengalami peningkatan dimana belanja modal pada tahun 2016 sebesar Rp. 217.45 milyar. Persentase peningkatan proporsi belanja modal hanya terjadi pada tahun 2015 dan 2016 dan hanya mampu memenuhi rata-rata proporsi belanja modal sebesar $20 \%$ jika dibandingkan dengan total belanja modal 2012-2014. Jika merujuk pada RPJMN tahun 2012-2014, Pemerintah Pusat memberikan target rata-rata realisasi belanja modal Pemda pada kisaran 26\%-30\% dari total belanja daerah. Menurut RPJMN Tahun 20152019 persentase belanja modal yang dialokasikan dalam ABPD sekurang-kurangnya $30 \%$ dari total belanja daerah. Kondisi ini menunjukan bahwa kurangnya perhatian dari pemerintah daerah untuk mendorong pertumbuhan ekonominya, sebab proporsi belanja modal yang dianggarkan masih rendah (Widiasih, 2017). Namun demikian untuk belanja operasional Kota Bima selama periode tahun 2012 sampai dengan tahun 2016 mengalami kenaikan tiap tahunnya, dimana jumlah belanja operasional yang tinggi di dominasi oleh besaran jumlah belanja pegawai yang mencapai 58\% dari total belanja daerah.

Perbandingan total belanja langsung dan belanja tidak langsung Kota Bima tahun 2012-2016 disajikan pada tabel 3, yang menunjukkan realisasi belanja langsung yang lebih besar dari Belanja tidak langsung. Penentuan besaran ideal antara belanja tidak langsung maupun belanja langsung pada dasarnya belum ada ketentuan yang mengatur nya tetapi setidak-tidaknya pemerintah daerah lebih besar memanfatkan anggaran yang tersedia untuk memenuhi anggaran belanja yang berkaitan langsung dengan pelaksanaan program dan kegiatan terutama yang menyangkut pelayanan publik. Ketika anggaran yang tersedia sebagian besar terserap untuk memenuhi kebutuhan belanja-belanja rutin (gaji dan tunjangan pegawai) maka hal ini akan berdampak pada pengalokasian belanja yang tidak efektif. Argumentasi ini sejalan dengan temuan penelitian yang dilakukan oleh Pankey dan Sherly (2015) menunjukkan bahwa anggaran belanja tidak langsung yang tidak efisien disebabkan karena digunakan keseluruhan untuk belanja tidak langsung bahkan melampau anggaran yang di rencanakan. Namun demikian hal ini sulit diterapkan karena mengingat porsi pegawai di pemerintah daerah pada umumnya cukup besar. Untuk mengatasi hal tersebut, selayaknya pemerintah daerah mengkaji kembali kebutuhan pegawai agar nantinya tidak menjadi beban dalam APBD.

Dengan besarnya anggaran yang terserap untuk menutupi kebutuhan belanja tidak langsung maka dengan sendirinya anggaran belanja untuk melaksanakan program dan kegiatan akan berkurang yang konsekuensinya adalah terhambatnya pelaksanaan pembangunan dan pelayanan publik didaerah. Temuan penelitian ini juga sejalan dengan argumentasi yang dinyatakan dalam studi Yudartha (2018) bahwa proporsi belanja lebih dominan pada belanja tidak langsung di bandingkan dengan belanja langsung daerah. Hal ini berarti belanja pemerintah masih belum mencerminkan kepentingan publik, sebab pengalokasian belanja tidak di alokasikan untuk belanja yang produktif yang dapat meningkatkan pelayanan publik.

Tabel 3. Total Belanja Langsung dan Belanja Tidak Langsung Kota Bima Tahun 2012-2016

\begin{tabular}{ccc}
\hline Tahun & Belanja Tidak Langsung & Belanja Langsung \\
\hline 2012 & 211.122 .598 .945 & 143.696 .728 .429 \\
2013 & 327.859 .695 .627 & 205.481 .142 .595 \\
2014 & 364.548 .063 .835 & 236.371 .212 .660 \\
2015 & 390.040 .654 .466 & 310.279 .536 .935 \\
2016 & 408.607 .020 .852 & 379.723 .702 .470 \\
\hline
\end{tabular}

Sumber: Realisasi APBD Kota Bima Tahun 2012-2016 (Diolah) 
Tabel 3 di atas menunjukkan bahwa Pemerintah Kota Bima selama 5 (lima) tahun anggaran belanja tidak langsung lebih tinggi dari pada anggaran belanja langsung. Tidak dipungkiri belanja langsung tersebut di dominasi oleh belanja pegawai menyebabkan belum efektif nya pengalokasian dana perimbangan berupa DAU untuk menggenjot pembangunan di daerah. Hal ini sejalan dengan pernyataan yang disampaikan oleh informan berikut ini:

"kebutuhan untuk belanja rutin aparatur di Kota Bima itu begitu tinggi, jadi untuk bayar gaji pegawai dan sebagai nya, kedua terjadi ke tidak efisiensi belanja oleh pemerintah daerah, jadi efisiensi maksud nya belanja yang hanya butuh 100 jadi 150, jadi pemda tidak membelanjakan secara tidak efisien uang yang ada”.

Selain ketidakefisien belanja daerah, pengalokasian belanja modal tidak dialokasikan ke belanja yang produktif baik peningkatan perekonomian daerah. Seperti yang di sampaikan oleh informan berikut ini:

"Belanja belanja yang dilakukan oleh pemerintah itu banyak yang tidak efektif, tidak efektif untuk memberikan pelayanan kepada masyarakat dan juga tidak efektif untuk mendorong agar PAD itu naik.

Berdasarkan pernyataan yang disampaikan oleh informan mengindikasikan bahwa alokasi DAU kebanyakan digunakan belanja operasi dan hal ini sinkron dengan data Kota Bima yang menunjukkan bahwa dalam kurun waktu 5 tahun terakhir belanja operasi mencapai angka rata-rata $77 \%$ dari belanja daerah. Jumlah belanja operasional yang tinggi di dominasi oleh besaran jumlah belanja pegawai yang mencapai 58\% dari total belanja daerah. Jika merujuk pada RPJMN tahun 2012-2014, pemerintah pusat memberikan target rata-rata realisasi belanja modal Pemda pada kisaran 26\%-30 \% dari total belanja daerah. Sedangkan RPJMN tahun 2015-2019 persentase belanja modal yang dialokasikan dalam ABPD sekurang-kurangnya 30\% dari total belanja daerah, yang kedua belanja itu tidak efisien. Tinggi nya proporsi belanja pegawai di tingkat daerah tidak lepas dari adanya berbagai kebijakan pemerintah daerah itu sendiri misalkan pengangkatan tenaga honor daerah yang terus menerus tanpa memperhatikan keterbatasan anggaran menyebabkan belanja menjadi tidak efisien. Selain itu belanja yang tidak efektif tidak untuk peningkatan pelayanan dan kesejahteraan masyarakat.

Dengan demikian besarnya anggaran dana transfer dari pusat berupa DAU tidak diikuti dengan besarnya pengeluaran untuk belanja modal yang bisa memberikan pelayanan berupa sarana dan prasarana kepada masyarakat. Seharusnya kenaikan DAU akan berimplikasi terhadap pemanfaatan DAU di daerah, karena pemerintah daerah mengharapkan DAU dari pusat meningkat tiap tahunnya. Kenaikan jumlah DAU yang meningkat tiap tahun dan untuk belanja yang produktif akan dapat meningkatkan pelayanan publik, kesejahteran masyarakat dan memajukan perekonomian daerah. Pernyataan tersebut didukung dengan data Kota Bima yang dalam kurun waktu 5 tahun selama tahun 2012-2016 lebih mengandalkan DAU sebagai penyumbang pendapatan daerah terbesar dengan persentase mencapai $72 \%$. Namun demikian untuk belanja modal pemerintah selama kurun waktu 5 tahun hanya mencapai $21 \%$. Dari sisi penerimaan daerah penguatan kualitas pemanfaatan DAU di daerah perlu di tingkatkan, dan penggunaan DAU yang lebih dominan hanya untuk belanja pegawai perlu dievaluasi kembali. Mengingat peran DAU yang strategis dalam APBD maka perlu diikuti dengan tata kelola DAU yang baik agar tujuan DAU dalam pemerataan kemampuan keuangan antar daerah dapat terwujud sekaligus mampu mendorong konvergensi tingkat pelayanan publik dan kesejahteraan antar daerah. 
Selain penggunaan DAU dapat kiranya ditindaklanjuti secara positif dan konstruktif untuk meningkatkan kesinambungan APBD dan peningkatan kualitas kebijakan desentalisasi fiskal, begitu pula dengan Dana Alokasi Khusus. Instrumen kebijakan desentralisasi fiskal yang secara langsung dapat mempengaruhi kualitas belanja pemerintah daerah adalah dana alokasi khusus (DAK). Dana Alokasi Khusus adalah dana yang bersumber dari APBN yang dialokasikan kepada daerah tertentu dengan tujuan untuk membantu mendanai kegiatan khusus yang merupakan urusan daerah sesuai dengan prioritas nasional. Peraturan Pemerintah (PP) Nomor 55 Tahun 2005 menyebutkan bahwa DAK dialokasikan kepada daerah tertentu untuk mendanai kegiatan khusus yang merupakan bagian dari program yang menjadi prioritas nasional dan menjadi urusan daerah. Pengalokasian DAK dimaksudkan untuk membantu daerah mendanai kebutuhan fisik sarana dan prasarana dasar yang merupakan prioritas nasional di bidang pendidikan, kesehatan, jalan, irigasi, air minum, senitasi, prasarana pemerintahan, kelautan dan perikanan pertanian, lingkungan hidup, keluarga berencana, kehutanan, sarana dan prasarana perdesaan serta perdagangan.

Pelaksanaan DAK didaerah sudah menggunakan aturan pelaksanaan APBD, dimana ruang lingkup pengelolaan keuangan DAK di daerah meliputi perencanaan, penganggaran, pelaksanaan dan penatausahaan keuangan, pertanggungjawaban pelaksanaan anggaran, pembinaan dan pengawasan serta pengelolaan barang/jasa yang bersumber dari DAK, sebagaimana di atur dalam Permendagri Nomor 20 tahun 2009 tentang Pedoman Pengelolaan Keuangan dana alokasi khusus di daerah. Namun demikian fakta yang terjadi pengalokasian DAK di banyak daerah masih belum efektif pelaksanaan nya, dimana DAK yang di lontarkan belum mampu untuk memberikan peningkatan pelayanan pada masyarakat. Disamping itu hasil kajian mengenai analisis permasalahan dan dampak dana alokasi khusus selama ini belum memberikan kontribusi signifikan terhadap tujuan (outcomes dan impact) pembangunan. Hasil penelitian ini mendukung penelitian Nuryadi dan Sri (2017) yang menganalisis dan mengevaluasi dampak dana alokasi khusus terhadap indikator kinerja pembangunan di daerah dan menemukan bahwa alokasi DAK (secara total) tidak berpengaruh signifikan terhadap PDRB per kapita Kabupaten/Kota. Oleh karena itu, secara umum dapat disimpulkan bahwa DAK, baik menurut alokasi bidang maupun secara total, belum memberikan dampak yang signifikan terhadap pelayanan publik dan kesejahteraan masyarakat. Hal ini dikarenakan memang arah penggunaan DAK yang memang belum secara langsung digunakan untuk "membangun", namun hanya untuk "memelihara". Oleh karena itu, DAK dirasa belum cukup efektif dalam upaya mencapai sasaran prioritas nasional yang menjadi bagian dari urusan daerah. Hasil penelitian ini juga sejalan dengan studi Karlina et al. (2017) pada Kabupaten Banjar yang menunjukkan bahwa pemanfaatan dana DAK sampai saat ini masih terbatas sebagai penambah aset daerah, belum dimanfaatkan sebagai penunjang program kesehatan, misalnya untuk promotif dan preventif. Selain itu penelitian ini juga menunjukkan bahwa peningkatan anggaran dan penambahan alokasi pada DAK setiap tahun ternyata belum mengubah pembangunan kesehatan masyarakat di Kabupaten Banjar. Hasil penelitian ini juga mendukung studi Yaqin et al. (2018) yang menunjukan bahwa alokasi belanja daerah khususnya pada pengalokasian belanja DAK belum mendatangkan hasil dan manfaat yang maksimal, baik untuk peningkatan kesejahteraan masyarakat maupun peningkatan perekonomian daerah.

Suatu kegiatan operasional dikatakan efektif apabila proses kegiatan mencapai tujuan dan sasaran akhir kebijakan (spending wisely) yang dapat menghasilkan perbaikan pelayanan kesejahteraan yang maksimal guna kepentingan masyarakat sehingga pada akhirnya kesejahteraan masyarakat meningkat. Namun demikian pada kenyataannya pelayanan kesejahteraan belum sepenuhnya dirasakan karena outcome 
belum bisa diukur yaitu dampak dari penyelenggaraan kegiatan pemerintah tersebut pada peningkatan kesejahteraan masyarakat. Argumentasi tersebut dinyatakan dalam pernyataan yang di kutip dalam penelitian Yaqin et al. (2018) berikut ini:

"Untuk di Kota Bima belanja memang belum berorentasi ke kinerja, outcome kita untuk apa sih ini? yang penting anggaran habis, konsep nya masih di penyerapan anggaran aja, tetapi uang ini benar-benar berdaya guna atau berhasil guna nya tidak di perhatikan.

Pernyataan informan di atas menunjukkan bahwa alokasi belanja daerah terutama pada pengalokasian belanja DAK belum berorientasi pada anggaran berbasis kinerja, dimana hanya berfokus pada input bukan pada outcome/dampak dari adanya pogram-program pembangunan terhadap masyarakat. Berdasarkan hasil analisis FGD, dalam diskusi permasalahan dan dampak dana Alokasi Khusus (DAK) menemukan bahwa prosedur pengalokasiannya kurang dikoordinasikan dengan pengalokasian dana dekonsentrasi dan tugas pembantuan, sementara terkait hal pelaporan tidak banyak pemda yang melakukan. Akibat permasalahan/kendala tersebut, sebagian daerah kesulitan menyerap atau memanfaatkan DAK sesuai sasaran yang ditetapkan. Seperti kasus yang terjadi di pengalokasian DAK irigasi dan air minum di pemerintah daerah Kota Bima (Yaqin et al., 2018) yang mengungkapkan bahwa sistem pelaporan belum dapat memperlihatkan jumlah penerima manfaat dari sarana air minum terbangun sehingga kinerja pelaksanaan DAK tahun sebelumnya belum dapat diukur kontribusinya terhadap peningkatan akses air minum oleh masyarakat.

Berikut ini data yang menunjukkan anggaran dana alokasi khusus air minum PU Kota Bima Tahun 2012-2015.

Tabel 4. Anggaran Dana Alokasi Khusus Air Minum PU Kota Bima Tahun 2012-2015

\begin{tabular}{ccc}
\hline Tahun & Target & Realisasi \\
\hline 2012 & 823.740 .000 & $100 \%$ \\
2013 & 1.010 .260 .000 & $100 \%$ \\
2014 & 1.089 .130 .000 & $100 \%$ \\
2015 & 1.653 .410 .000 & $100 \%$ \\
\hline
\end{tabular}

Sumber : PU Kota Bima. Data di olah, (2016)

Anggaran untuk Dana Alokasi Khusus (DAK) untuk penyediaan air minum Kota Bima selama periode 4 tahun terakhir selama tahun 2012-2015 selalu mengalami peningkatan tiap tahun nya. Begitu juga dengan realisasi nya dimana realisasi dari tahun 2012-2015 mencapai 100\% menunjukkan bahwa pembangunan fisiknya sudah di laksanakan dengan baik dalam arti sudah sesuai dengan target RPJMN tahun 20152019. Akan tetapi permasalahannya adalah apakah peningkatan anggaran DAK air minum dari tahun ke tahun atau dengan realisasi fisik mencapai $100 \%$ dapat memberikan kontribusinya terhadap peningkatan akses air minum untuk masyarakat dan berapa masyarakat yang terlayani dengan adanya program tersebut. Kutipan yang mendukung argumentasi tersebut disampaikan oleh informan berikut ini :

"Evaluasi ke pusat itu adalah laporan nya tercapai pembangunan fisik nya tapi tidak mengevaluasi outcome nya. outcome ya kalau output nya dia sudah membangun bor pipa melayani sekian SR (sambungan rumah) setiap KK tapi outcome nya $45 \mathrm{KK}$ itu terlayani air bersih itu yang perlu di uji bener ngga 
menerima air bersih ketika fisik itu sudah 100\%. itu yang tidak pernah di uji. Makanya kenapa fungsi pengendalian dari kita masih lemah”.

Dari penjelasan informan tersebut mengindikasikan bahwa permasalahan pada sistem pelaporan yang belum dapat memperlihatkan jumlah penerima manfaat dari sarana air minum. Selain itu pemerintah hanya sekedar membangun sistem perpipaan untuk penyediaan air minum tanpa melakukan monitoring dan evaluasi pelaksanaan program yang sudah di bangun dan dampak nya terhadap pelayanan pada masyarakat. Seperti yang disampaikan oleh informan mengindikasikan bahwa pemerintah daerah sekedar membangun fasilitas dengan realisasi fisik mencapai 100 persen tanpa di lakukan evaluasi terhadap sarana yang sudah di bangun dan apakah pembangunan ini memberikan dampak bagi masyarakat dengan indikator terlayani masyarakat dengan adanya program tersebut.

Dengan demikian pendekatan pengalokasian DAK semestinya bergeser dari berbasis input (input based) menjadi pendekatan berbasis hasil (output/outcomes based). Dalam hal ini penetapan berbasis output/outcomes memerlukan indikatorindikator kinerja kunci yang relevan dan terukur termasuk indikator-indikator yang relevan dengan standar pelayanan umum sehingga dengan adanya outcome ini dapat diukur pencapaian pemanfaatan DAK yang dikucurkan kepada pemerintah daerah memiliki pencapaian sasaran yang jelas. DAK memainkan peran strategis dalam dinamika pembangunan sarana dan prasarana pelayanan dasar di daerah, sehingga sudah seharusnya pengalokasian DAK ini sendiri di lakukan secara efektif guna mendorong pencapaian pelayanan dasar di daerah. Begitu juga dengan DAU yang perlu penyempurnaan formula DAU agar benar-benar harus diprioritaskan mengingat DAU merupakan komponen pembiayaan terbesar dari Dana Perimbangan sekaligus sumber penerimaan terbesar bagi Pemerintah Kota Bima, sehingga pengalokasiannya tidak hanya untuk belanja rutin (gaji pegawai) melainkan mampu meningkatan pelayanan publik dan pertumbuhan ekonomi di daerah. Selain itu perlu Peningkatan efektivitas pelaksanaan monitoring dan evaluasi Dana Perimbangan yang bertujuan untuk meningkatkan kinerja pemerintah daerah, terkait dengan kinerja dan capaian program yang sudah dilaksanakan, dengan meningkatkan evaluasi dapat menilai efektivitas dari masing masing aktivitas terhadap program yang disusun oleh pemerintah daerah.

\section{Kesimpulan, Implikasi dan Keterbatasan}

Pengelolaan Dana Perimbangan di daerah Kota Bima Baik DAU maupun DAK belum Efektif yang terlihat dari besarnya anggaran dana transfer dari pusat berupa DAU tidak di ikuti dengan besarnya pengeluaran belanja modal karena pemerintah daerah masih berkonsentrasi kepada masalah administrasi, sehingga belum efektif dalam meningkatkan pelayanan publik. Alokasi belanja DAK belum efektif dan belum berorientasi ke anggaran berbasis kinerja karena arah penggunaan DAK hanya berfokus pada input bukan pada outcome dari program-program yang dapat meningkatkan pelayanan publik, kesejahteran masyarakat dan memajukan perekonomian daerah. Sistem pelaporan yang juga belum dapat memperlihatkan jumlah penerima manfaat dari sarana yang terbangun sehingga kinerja pelaksanaan DAK tahun sebelumnya belum dapat diukur kontribusinya terhadap peningkatan akses sarana serta belum dilakukan monitoring dan evaluasi pelaksanaan program dan dampaknya terhadap pelayanan pada masyarakat. Oleh karena itu perlu upaya untuk meningkatkan efektivitas penggunaan dana perimbangan baik DAU maupun DAK sehingga dapat dialokasikan ke belanja yang mendukung peningkatan pelayanan publik dan pertumbuhan ekonomi di daerah. 
Implikasi penelitian ini mengarah kepada pentingnya upaya untuk meningkatkan monitoring dan evaluasi terhadap pelaksanaan urusan pemerintah daerah terkait dengan pengalokasian pendapatan daerah yang di gunakan untuk membiayai program kegiatan daerah, yang dalam hal ini terkait dengan dana perimbangan yang berasal dari DAU maupun DAK. DAK memainkan peran strategis dalam dinamika pembangunan sarana dan prasarana pelayanan dasar di daerah, sehingga sudah seharusnya pengalokasian DAK ini sendiri di lakukan secara efektif guna mendorong pencapaian pelayanan dasar di daerah. Penelitian ini memiliki keterbatasan yang dapat dikembangkan pada penelitian mendatang. Penelitian ini hanya fokus pada permasalahan alokasi dana perimbangan DAU dan DAK sehingga penelitian mendatang dapat mengembangkan pada dampak alokasi dana transfer pada penilaian kinerja pengelolaan keuangan di daerah. Penelitian mendatang juga dapat menganalisis pengelolaan anggaran lainnya di daerah, dengan menggunakan indikator kinerja pengelolaan anggaran lainnya yang relevan sehingga dapat menggambarkan secara lebih jelas dan menyeluruh permasalahan mengenai pengelolaan keuangan di daerah.

\section{Referensi}

ADB. 2011. Proposals for Reform of the Special Allocations Grant (DAK).Badan Pengelolaan Keuangan dan Aset Daerah Kota Bima. Bappenas. 2012. Analisis Perspektif, Permasalahan, dan Dampak Dana Alokasi Khusus (DAK). White Paper. Jakarta: Bappenas.

Agustino, Leo. 2016. Dasar-Dasar Kebijakan Publik. Bandung: Alfabeta

Halim, Abdul. 2007. Akuntansi Sektor Publik Akuntansi Keuangan Daerah. Edisi Revisi, Jakarta: Salemba Empat.

Handayani, A. 2009. Analisis Pengaruh Transfer Pemerintah Pusat terhadapPengeluaran Daerah dan Upaya Pajak (Tax Effort) Daerah (Studi Kasus: Kabupaten/Kota di Jawa Tengah). Skripsi Tidak Dipublikasikan. Universitas Diponegoro Semarang

https://economy.okezone.com/read/2017/12/01/20/1823858/sri-mulyani-sebut-daerahkecanduan-dana-transfer-dari-pemerintah-pusat. Diakses pada tanggal 1 Maret 2019).

https://economy.okezone.com/read/2017/12/01/20/1823863/apbd-habis-hanya-untukbayar-gaji-pns. Di akses pada tanggal 1 Maret 2019.

Karlina. Laksmiarti, T. Kusnali, A. 2017. Kontribusi Dana Alokasi Khusus Terhadap IPKM dalam Pelaksanaan Pembangunan Kesehatan di Kabupaten Tapin dan Banjar Provinsi Kalimantan Selatan. Buletin Penelitian Sistem Kesehatan, 20 (2), 73-81

Mardiasmo. 2002. Akuntansi Sektor Publik. Yogyakarta : Penerbit Andi.

Miles, Matthew B. \& A. Michael Huberman. 1992. Analisa Data Kualitatif. Universitas Indonesia (UI-Press) - Jakarta

Nurkhayat, A. Firdaus, M. Mulatsih, S. 2018. Strategi Optimalisasi Pengelolaan Dana Perimbangan di Indonesia. Jurnal Manajemen Pembangunan Daerah, 10 (1), $35-$ 47. 
Nuryadin, D. Sri, S. 2017. Analisis dan Evaluasi dampak Dana Alokasi Khusus Terhadap Indikator Kinerja Pembangunan di Daerah Studi Kasus Kabupaten-Kota 2003-2013. Jurnal Ekonomi dan Studi Pembangun, 18 (1), 63-68

Pankey, I. \& P. Sherly, P.2015. Analisis Efektivitas dan Efisiensi Anggaran Belanja pada Dinas Kebudayaan dan Pariwisata Provinsi Sulawesi Utara. Jurnal Riset Ekonomi Manajemen dan Akuntansi, 3 (4), 33-43

Peraturan Pemerintah Republik Indonesia. Nomor 55 Tahun 2005 Tentang Dana Perimbangan.

Sugiyono. 2014. Metode Penelitian Kuantitatif, Kualitatif dan R\&D. Bandung: Alfabeta.

Undang-Undang Republik Indonesia Nomor 32 Tahun 2004 Tentang Pemerintah Daerah.

Undang-Undang Republik Indonesia Nomor 33 Tahun 2004 Tentang Dana Perimbangan antara Pusat dan Daerah.

Undang-Undang Republik Indonesia Nomor 33 Tahun 2004 Tentang Dana Perimbangan antara Pusat dan Daerah.

Yaqin, A.U.; T. Herwanti \& Akram. 2018. Komitmen Pemerintah Daerah Dalam Pengelolaan ABPD. e-Jurnal Akuntansi Universitas Udayana, 25(3), 2321-2351.

Widiasih, Ni Nyoman. Gayatri. 2017. Pengaruh Pendapatan Asli Daerah, Dana Alokasi Umum, Dana Bagi Hasil pada Belanja Modal Kabupaten/Kota di Provinsi Bali. EJurnal Akuntansi Universitas Udayana, 18 (3), 2143-2171.

Yudartha, P.D. 2018. Komitmen Pemerintah Daerah dalam Mewujudkan Anggaran Pro Publik melalui Anggaran Pendapatan dan Belanja Daerah Kabupaten Klungkung. Tesis. Program Studi Administrasi Universitas Udayana.

Yin, Robert K. 2015. Studi Kasus: Desain \& Metode. Jakarta: Rajawali Press. 